2005-09-01

\title{
Testing for a Critical Juncture: Change in the ICTU's Influence Over Public Policy in 1959
}

John Hogan

Technological University Dublin, john.hogan@tudublin.ie

Follow this and additional works at: https://arrow.tudublin.ie/buschmarart

Part of the Political Science Commons

\section{Recommended Citation}

Hogan, J: Testing for a critical juncture: change in the ICTU's influence over public policy in 1959. Irish Political Studies, Volume 20, Number 3, pp. 23-43.

This Article is brought to you for free and open access by the School of Marketing at ARROW@TU Dublin. It has been accepted for inclusion in Articles by an authorized administrator of ARROW@TU Dublin. For more information, please contact arrow.admin@tudublin.ie, aisling.coyne@tudublin.ie,gerard.connolly@tudublin.ie.

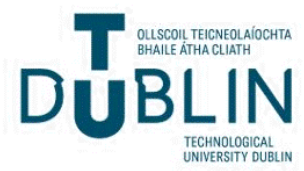


Testing for a Critical Juncture: Change in the ICTU's

Influence Over Public Policy in 1959 
The paper seeks to improve our understanding of the concept of critical junctures. Critical junctures have been used to provide avenues for exploring change in historical institutionalism. However, the critical junctures concept, as it has developed, lacks rigour. We have no means of saying, with certainty, what is a critical juncture. If we cannot define a critical juncture the issue of path dependency becomes nebulous, as we cannot be certain as to path origins. Over the years the critical junctures concept has been used in conjunction with "watersheds" in politics, but without any quantifications. This has left the approach in a quandary. Consequently, historical institutionalists have been more inclined to look to other approach to identify change.

Improving upon the critical junctures approach involves specifying standards that enable identification of levels of change. The remoulded approach is employed here in examining change in the Irish Congress of Trade Unions' (ICTU) influence over public policy in 1959. It will identify if this change in the unions' influence over public policy constituted a critical juncture. This example will illustrate how the remoulded approach reduces uncertainty surrounding the issue of what level of change is necessary to constitute a critical juncture. What is more, the remoulded framework is applicable to any social science research concerned with change.
\end{abstract}

\title{
Introduction
}

For historical institutionalism the focus is choices made early in the history of a polity. These choices will have a persistent influence (Peters, 1999, p. 210). When a government initiative starts down a particular path there is a tendency for choices to persist. Choices made at time $\mathrm{T}$ influence choices at time $\mathrm{T}+1$ (Berman, 1998, p. 380). Policies are path dependent, and once initiated continue until a sufficiently strong force deflects them (Krasner 1984, p. 240). Consequently, institutions are not easily altered when conditions change (Schickler 2001; Stark and Bruszt 1998).

Historical institutionalism is effective at explaining what happens, and in weaving a narrative that captures a good deal of the reality of history. However, these characterisations of history come close to being functionalist. The problem is that there are cases in which institutions change in unexpected ways, and the approach appears at a loss to explain them. 'This is the weakest and most difficult point in institutionalist analysis,' (Rothstein, 1996, p. 153). 'Historical institutionalism is not a fertile source of explanations for change in organisations and institutions' (Peters, 1999, p. 70).

However, Pierson (2004, pp. 5-6) argues that many of the key concepts needed to underpin analyses of temporal processes, such as path dependency and critical junctures have received only limited discussion. This raises questions as to both the understanding, and employment, of these concepts. Consequently, critical junctures 
have remained under examined and insufficiently specified. This paper focuses on critical junctures, seeking to outline a framework within which to identify them, and consequently the change points. If a critical juncture can be identified then we can point to a period of change as significant with a greater degree of confidence than previously.

This paper, in seeking to improve our understanding of critical junctures, is divided into a number of sections. The first section focuses on the issue of path dependency, and the problems within political science (historical institutionalism) in identifying change. The next section discusses the characteristics of critical junctures, the use of the approach, its weaknesses, and how the approach is remoulded to give it the rigour it previously lacked. Thereafter the paper discusses the methodology employed, and case study undertaken, to test the remoulded approach. The conclusion will summarise the arguments and findings of the paper.

\section{$\underline{\text { An Exploration of Institutional Change }}$}

There has been surprisingly little attentiveness in political science to the specifically temporal dimensions of social processes. 'In contemporary social science, the past serves primarily as a source of empirical material, rather than as a spur to serious investigations of how politics happens over time' (Pierson, 2004, p. 4). An exploration of the temporal dimensions of social processes is the weakest link in social science's historical turn. We lack a clear outline of why the investigation of issues of temporality is critical to an understanding of social processes.

Exploring social mechanisms with a strong temporal dimension can address the desire of historically orientated scholars to capture how history matters. The identification and clarification of such mechanisms can enhance our ability to develop arguments about temporal processes that are both convincing and have at least limited portability. This brings us to the issue of institutional change. In historical institutionalism there is no clear theory of how and why institutions change, with the exception of punctuated equilibrium. However, 'the problem with this model is that institutions explain everything until they explain nothing' (Thelen and Steinmo, 1992, p. 15). In stable periods institutions are independent variables used to explain outcomes, but during periods of breakdown, following crises, the status of institutions is inverted. They become dependent variables, their design at the mercy of political conflicts consequent of the break down.

In the context of temporality we turn to critical junctures. Watersheds open and close opportunities that shape political life for years thereafter (Lipset and Rokkan, 1967, p. 37). Periods of institutional genesis correspond to critical junctures (Abbott, 1997). Critical junctures are characterised by the adoption of a particular institutional arrangement from among various alternatives (Mahoney, 2000, p. 512). Levi (1997) argues that the juncture is critical as once an option is selected it becomes progressively more difficulty to return to the initial point when alternatives were available.

Critical junctures establish pathways that funnel units in particular directions, the paths spoken of in path dependency. Once units move in a particular direction they realise increasing returns, and continue in that direction (Mahoney, 2003, p. 53). This points to the importance of the past to explain the present, and highlights the need for a broad historical vantage point. Moreover, this 'suggests the importance of focusing on the formative moments for institutions and organisations (Pierson, 1993, 
p. 602). While not maintaining that critical junctures are the only source of change or innovation, critical junctures can discredit existing institutions and policies, triggering change (Cortel and Peterson, 1999, p. 184).

\section{The Use of the Critical Junctures Approach}

Until now the character of critical junctures, and the perspective from which they are analysed, has varied greatly. Some critical junctures may involve considerable discretion, whereas others appear embedded in antecedent conditions. The duration of a critical juncture may involve a brief period in which one direction or another is taken, or can constitute an extended period of reorientation (Mahoney 2001).

The analysis of critical junctures has recently been finding wider employment in comparative politics. Critical junctures have been used to understand the trajectories of national development in Latin America (Collier and Collier, 1991). Examining the preconditions for institutional reform in Switzerland, Armingeon and Beyeler (2001, p. 6) ${ }^{1}$ refer to critical junctures as windows of opportunity for policy makers. Garrett and Lange (1995, p. 628) argue that electoral landslides create critical junctures by producing overwhelming mandates for policy and/or structural change. Garrett (1993, p. 523) writes of this in relation to the emergence of "two of the most successful instances of structural change in the twentieth century: social democracy in Sweden after the Great Depression, and neoliberalism in Thatcher's Britain.' Casper and Taylor (1996) argue that critical junctures can be used in analysing periods when authoritarian regimes are vulnerable to liberalisation. The approach has been utilised in examining watershed in American trade policy (Haggard, 1988, p. 91), the political dynamic of the Chiapas conflict (Vargas, 2004), and the emergence of occupational welfare in Israeli (Gal and Bargal, 2002). Karl (1997) refers to critical junctures in her analysis of how "petro-states" become locked into problematic development paths. Although the perspective's importance is evident in cross-national studies, it is also useful in research on long-term patterns of change within countries (Brady, 1988).

Arguments about critical junctures have been important to research on labour politics. Kerr (1960, p. 235) emphasises the long-term stability of the industrial relations systems crystallised at relatively early stages. Valenzuela (1979) shows how the filling of organisational space during crucial phases of labour movement development freeze organisational alternatives within the labour sector. Lipset (1983, p. 1) analyses how the historic conditions under which the proletariat entered the political arena shaped the subsequent emergence of reformist, as opposed to revolutionary, labour movements.

The critical juncture's approach concentrates on historical causes (Stinchcombe, 1968, pp. 101-29). Here a set of causal factors brings about an outcome, or legacy, at a particular point, and the pattern that is instituted reproduces itself without recurrence of the original cause. Central to the process of reproduction is that institutions create vested interests, and power holders therein seek to perpetuate their own positions (Verba, 1971, p. 308). This suggests a path dependent pattern of change in which outcomes during a crucial transition establish distinct trajectories within which one incident follows another (David, 1985, p. 332).

The traditional understanding of trade union politics, and state-union relations, suggests it is an area where a given constellation of political relationships, once institutionalised, has a tendency to persist. This suggests that a critical juncture 
framework is appropriate in the analysis of trade union politics (Collier and Collier, 1991, p. 37).

\section{Remoulding the Approach}

A significant problem is that a set of universally applicable criteria by which to assess potential critical junctures to discover if they are critical junctures, or cases of change that have taken place incrementally, does not exist. While acknowledging that the development of a set of universally applicable rigorous standards for exploring critical junctures would be near impossible, in light of the vast milieu of topics under examination in political science, at least moving in that direction would constitute an advance for the discipline. Thus, we are left wrestling with contradictory necessities, the need to be more rigorous - to advance the approach, and the requirement to be broadly applicable, if the approach is to be of use to the discipline as a whole. Consequently, the standards developed have to be broad and encompassing.

The paper seeks to improve our understanding of the concept of critical junctures, and political change. It seeks to 'flesh out the often-invoked but rarely examined declaration that history matters' (Pierson, 2004, p. 2). The paper argues that the critical junctures concept, as it has developed, lacks rigour. Improving upon the approach will involve specifying clearly defined standards that enable the identification of levels of change in order to see whether or not a specific period of change constitutes a critical juncture. These standards will make the approach operationalisable and falsifiable. What is more, this focus on the temporal dimension provides possibilities for shaping some common or overlapping intellectual terrain for scholars working in diverse research traditions (Pierson, 2004 p. 8).

The idea of critical junctures is endowed with the richness of the observation that history matters. The analysis of what Pierson (2004, p. 77) calls 'temporal ordering' is central to the claim that history matters. But, even though analysts increasingly invoke the concept of path dependence, clear definitions are rare. This is where clarity in regard to the progenitors of paths in path dependency, the critical junctures, becomes important. At least if we are clear about the beginnings this should help us in later efforts to clarify wider definitions encompassing path dependency. In relation to the causal chain arguments, and the infinite regress problem, a clear understanding of a critical juncture would provide us with a clear break in the chain with which to define the starting point for our analysis. As Mahoney (2001, p. 8) puts it, 'critical junctures provide a basis for cutting into the seamless flow of history.'

In 1991 Collier and Collier set out a generalised framework for analysing change, this to determine if certain changes constituted critical junctures. In 2001 Mahoney, utilising the Collier's framework, sought to explain why the different experiences of the nineteenth century liberal period in five Central American countries constituted key critical junctures in their histories. However, there was no systematic approach, or rigorous framework, for determining when change was sufficient to constitute a critical juncture. Consequently, a question that arises is how to distinguish between a critical juncture, and incremental change that is relatively swift? Thus, while answering the question may place restrictions on the liberty with which the term is used, at least now one will be able to say with greater certainty what is a critical juncture. 
To be able to recognise what is a critical juncture, we must be able to recognise what is not. Not all events, even seemingly significant events, can be critical junctures. A critical juncture must be an event that puts our chosen unit, or units, of examination onto particular paths to development. Prior to the critical juncture, a range of possibilities must exist for those units, afterwards these possibilities will have mostly vanished, replaced by a particular enduring legacy. It is here at the narrowing point, where possibilities close off, that we must seek a means of defining critical junctures.

We argue that two separate elements are required for a critical juncture. Firstly, it is necessary to identify the generative cleavage. This will involve an examination of the tensions that lead to the period of change. Secondly, for the change that takes place to constitute a critical juncture, as opposed to an incremental change, this change must be significant, swift, and have an enduring legacy (see Figure 1).

FIGURE 1: CRITICAL JUNCTURE

[Generative Cleavage] $\quad+$ [Change $\quad=$ [Critical Juncture $]$

(Significant; Swift; Enduring)

The literature on critical junctures views them from the perspective of cleavages, placing emphasis on the tensions that lead up to the critical juncture. Since these cleavages are seen as producing the critical juncture Valenzeula and Valenzuela (1981, p. 15) refer to them as generative cleavages. The generative cleavage to be examined will depend on the topic studied. 'Traditionally, students of institutional change focused on the importance of situations of large-scale public dissatisfaction, or even fear, stemming from an unusual degree of social unrest and/or threats to national security' (Cortell and Peterson, 1999, p. 184). Wars, revolutions, economic crises, changing balance of power, electoral landslides, and social movements may produce an overwhelming mandate for policy and or/structural change (Cortell and Peterson, 1999, p. 184). Such events discredit existing institutions and policies, triggering change (Tilly, 1975). As Katznelson (1997) states, the macro analysis of critical junctures that set countries along different developmental paths has been the bread and butter of historical institutionalism. However, critical junctures need not be attributed only to big exogenous shocks. Many, less dramatic, events could be found to constitute generative cleavages, contributing to change that is significant, swift and enduring. Within the framework set out here all that is necessary to test a case is a detailed examination of the evidence to see if it fits with the criterion for a critical juncture.

The issue of what constitutes significant change will vary as a function of the topic studied. But, instead of arguing, as in the past, that change must be significant, and saying no more on this matter, here we lay down standards for identifying the level of significance of change. These standards are to be measured qualitatively and quantitatively. Change of below a specified point is not classified as significant, while above a certain point the significance of the change is considered to increase through various levels - low, medium, and high. At a high level of significance the change would be considered noteworthy. Consequently, our search for critical junctures is not confined to large world-shattering events, but can refer to relatively small events, that if they occur at the right moment, can have large and enduring consequences. 
Because we are dealing with critical junctures, periods of significant change, we assume the change is not long and drawn out. We must reject the notion of incremental change if dealing with radical change at a point in time. Consequently, we add the notion of swiftness to our understanding of a critical juncture. The significant change must be quick. In the case below a swift change is taken to be one that occurs within twelve months. Ultimately, decisions as to swiftness will depend on the topic, and will, in all probability, be arbitrary. Nevertheless, the chosen standard for swiftness, having been set out, will have to be applied equally across all cases examined in the study, adding consistency to the examination of potential critical junctures. Then, at least, a standard will have been established to work with in the testing of cases.

If, as is frequently claimed in social analysis, outcomes at a critical juncture induce a path dependent process with increasing returns resulting, we shall keep the concept of a legacy resulting from a critical juncture. Collier and Collier (1991, p. 33) do not provide any criteria for minimum legacy duration. However, instead of just a vague notion that a critical juncture must have enduring after-effects, we assumed that for a change to be a critical juncture its after-effects should last for a minimum of at least one standard government's term of office. Although arbitrary, this is still specific to the topic under examination, and to an extent arbitrary measures are necessary when attempting to quantify that which has never been quantified previously. As King et al., (1994, p. 152) state in relation to social science research, 'a universally right answer does not exist: all measurement depends on the problem that the investigator seeks to understand.' While not setting a specific end point for the duration of a critical juncture's legacy, at least setting a minimum for its duration makes it easier to identify a critical juncture when examining change. Should the critical juncture have no legacy - then it was not a critical juncture. In other words, a particular and irreversible path was not laid down at the time of interest.

It is only through the examination of its historical legacy that the importance of a critical juncture can be established. Many social processes take a long time. Recognition of this fact is restricted in political science, with so much research focused on the immediate (Pierson, 2004, pp. 79-81). This is one of the benefits of the approach set out.

This definition of a critical juncture gives rise to four possible findings, as set out in the diagram (see Figure 2). It is only in the top left hand box that a critical juncture can be identified. In any of the other three locations the conditions for a critical juncture are not met. This diagram will be used here to illustrate the results of the various findings uncovered.

FIGURE 2: THE CRITICAL JUNCTURE GRID

\begin{tabular}{|r|l|l|}
\hline $\begin{array}{c}\text { Generative Cleavage } \\
\text { (Crisis) }\end{array}$ & \multicolumn{2}{|c|}{$\begin{array}{c}\text { Change (Significant, Swift, and Enduring) } \\
\text { YES }\end{array}$} \\
\cline { 3 - 3 } NO & GC + SSE = CJ & GC + No SSE = No CJ \\
\cline { 2 - 3 } & No GC + SSE = No CJ & No GC + No SSE = No CJ \\
& & \\
\hline
\end{tabular}


The remoulded critical juncture framework improves our ability to identify change. A common framework for analysing critical junctures is vital, as without it the validity of findings are questionable. The starting point for all path dependency arguments is weakened without a definitive answer as to whether there is a critical juncture at the initial branching point. The objective in setting the various criteria for assessment is to rigorously systemise the critical junctures approach. The use of this approach will enable the identification of what is, and what is not, a critical juncture. This addresses the uncertainties regarding critical junctures not answered by earlier approaches. The remoulded critical junctures approach ads an analytical tool to the historical institutional toolkit, allowing for a more coherent researching and understanding of past events.

To sum up, the argument in relation to critical junctures is that there must be a generative cleavage, along with a period of change that is significant, swift, and enduring. Should any of these conditions not be fulfilled then there was no critical juncture. This clarity in identifying what is a critical juncture is the approach's strength. This provides historical institutionalists with a useful tool in exploring and quantifying change. Ambiguity concerning the concept of critical junctures is removed.

While not purporting to have drawn up a panacea to the problem of identifying when a period of change is a critical juncture, this framework contributes towards answering that question in a way that is applicable across disciplines. This is the strength of the approach set out here. When employed in conjunction with narrative, analytical, and counterfactual analysis, the remoulded critical junctures approach can help the investigator identify what Aminzade (1992, p. 463) calls the "key choice points" the forks in the road.

\section{METHODOLOGY}

\section{The Choice of Trade Unions}

Institutions range from formal government structures, through legal institutions, to more amorphous social institutions. 'Just where to draw the line on what counts as an institution is a matter of controversy' (Thelen and Steinmo, 1992, p. 2). Included in their definition of institutions are such features of the institutional context as the structure and organisation of economic actors like trade unions.

Trade union peak organisations are interest groups active within the polity. The state actors and societal actors with whom the union peak organisations interact all operate inside the national institutional framework. For Steinmo (1989, pp. 503504) these frameworks are the context in which groups and individuals interpret their self-interest and thereby define their policy preferences. In this approach the trade union centres behave like any rational political actor, defining their policy preference and strategic objectives within the framework of the country's decision-making institutions.

Trade unions are usually the largest sectional interest groups in western societies. The influence of trade union peak organisations over public policy provides an arena in which to examine broad comparative questions. The power of trade unions is a central tenet in the ideological debate between left and right in various countries. The level of influence they wield within a polity can affect the formulation 
of economic and social policies, the distribution of wealth across the society, industrial relations policy, and the use and misuse of human resources.

The case study focuses on the changing influence of the ICTU over Irish public policy in 1959. This case study was chosen from a methodological viewpoint. This period was identified, after a preliminary examination, as constituting a good test case for the remoulded critical junctures approach, and its dependent variable. It appears that the ICTU's influence over Irish public policy increased dramatically in that year, and that this increased influence endured thereafter. This suggests at a critical juncture, and a consequential developmental path.

In political science, while we should not generalize from single cases, a singlecase design is appropriate when that case represents an example for testing a theory (Eisenhardt, 1989; see also Yin, 1994). Overall, the Irish trade union movement did well in the period 1959-1981. If this success can be called path dependent, did it stem from an identifiable critical juncture? The remoulded approach should be able to provide an answer.

\section{The Choice of Generative Cleavage}

Macroeconomic crises were chosen as the proxy for the generative cleavages, as they impact significantly upon both trade unions, and their peak organisations. As Collier and Collier (1991, p. 93) point out, labour movements and national economies are linked to one another, their roots, and evolutions, intertwined. 'Most scholars agree that severe recessions make significant structural changes possible because they render politics highly fluid' (Garrett, 1993, p. 522). The trade unions are exposed to the impact of economic fluctuations as their membership makes up the workforce of an economy, and they themselves are interest groups active within that political economy. This places an emphasis on the importance of the economic situation leading up to a critical juncture. However, this leaves us with a degree of subjectivity as to what constitutes a macroeconomic crisis.

However, it should be noted that there is the possibility that a generative cleavage other than a macroeconomic crisis could coincide with significant, swift, and enduring change in the trade unions' influence over public policy. Although employed here, macroeconomic crises are only one of any number of other proxies (as discussed above) that could be utilised for generative cleavages, provided adequately justified.

\section{Time Frame}

This paper will focus on change in trade unions' influence over public policy in Ireland in 1959. That year is noted by scholars as marking an important turning point for modern Ireland. The 1940s had been a decade of economic stagnation, but the late 1950s witnessed a revival. There was a shift in economic policy from protectionism to openness at the time when Sean Lemass became Taoiseach. If any period marked a significant turning point in the political economic history of Ireland 1959 would be a prime example. The change in the ICTU's influence over public policy may have constituted a critical juncture, as its contribution to national public policy making was dramatically enhanced thereafter. The case study will be examined using the criteria set out above in the remoulded critical junctures framework. The search for these 
criteria will enable us to determine whether or not we are dealing with a critical juncture.

\section{Hypotheses and Observable Implications}

In the context a trade union peak organisation as the case study, we must determine hypotheses that can used to test the remoulded critical junctures approach. The assumptions that for a critical juncture there must be a generative cleavage, and a coinciding period of change that is significant, swift and enduring, are used to derive the hypotheses and observable implications that are testable against empirical evidence.

The hypotheses are structured to correspond with the framework developed for examining critical junctures. The first hypothesis examines whether there was a generative cleavage at the time focused upon. The second hypothesis deals with the issue of change in trade union peak organisation influence over public policy. This encompasses the criteria of significant, swift, and enduring, change.

It must be recognised that when dealing with multivariate analyses based upon the qualitative examination of historical events we come up against the issue of assessing partial explanations. This realisation permits us to approach the search for, and utilisation of, empirical data with an understanding that the empirical-theoretical fit will vary between each observable implication, and between each hypotheses. To identify the extent of this variation it is necessary to classify the empirical-theoretical fit according to a scale running from none, through low and medium, to high. The findings will be set out in a table to see if the proposed critical juncture constituted a critical juncture.

\section{H1. If there was a critical juncture, then there must have been a generative cleavage (macroeconomic crisis).}

\section{Economic Data}

1. If the country's main economic indicators have reached decade-long lows, then the economy may have been in crisis.

One indicator at a decade-long low - no empirical-theoretical fit, two indicators - low empirical-theoretical fit, three indicators - medium empirical-theoretical fit, four indicators - high fit.

\section{Economic Opinions and Assessments}

2. If the media regard the economy as in crisis, there may have been a crisis.

3. If economic and political commentators regard the economy as in crisis, there may have been a crisis.

4. If the central bank regards the economy as in crisis, there may have been a crisis.

5. If the OECD regards the economy as in crisis, there may have been a crisis. 
If the above regard the economy as in crisis there is high empirical-theoretical fit, anything less than a crisis and the fit will be lower, how much lower depending on their assessment of the situation

\section{Elected Representatives}

6. If elected representatives regard the economy as in crisis, there may have been a crisis.

7. If government pronouncements on the economy are consistent with a crisis management approach, then may have been a crisis.

If the above regard economy as in crisis there is high empirical-theoretical fit, anything less than a crisis and the fit will be lower, how much lower depends on their assessment of the situation.

\section{H2. If there was a critical juncture, then change in trade union peak organisation influence over public policy must have been significant, swift, and enduring.}

This analysis will search for changes in the trade union peak organisations' policy preferences and relative power over public policy. This approach is not measuring the trade unions' influence per se, but looking for indicators of change in the relationship between the union peak organisation and government. The observable implications, sub-divided amongst the headings of access and attitudes, structures, government policies and trade union policies, and third party assessments of government - trade union relations are comprehensive. The independent variables were chosen to identify significant, swift, and enduring change in the relationship between the trade union peak organisation and government.

In classifying the empirical-theoretical fit according to a scale running from none, through low and medium, to high, the specific criteria shall be whether each of the observable implications underwent significant, swift, and enduring change. As set out above, swift refers to change taking place within months of the proposed critical juncture, while enduring requires that the critical juncture's after effects last for longer than a standard administration's term of office.

However, significance shall be the most important factor searched for, as without significant change there is little to indicate a critical juncture. The criteria for significance, being particular to each observable implication, will be set out individually. Should none of these criteria (significant, swift, and enduring) be found, then the empirical-theoretical fit for that observable will be none. Should one of these criteria be uncovered the empirical-theoretical fit for that observable implication will be low. If two of the criteria are found then the empirical-theoretical fit will be medium. Should all three of the criteria be found then the empirical-theoretical fit for that observable will be high.

\section{Access and Attitudes}

1. If the unions' rate of meetings with the prime minister changed significantly, swiftly, and enduringly, then the unions' influence over public policy may have changed.

Change of below 10 per cent - no significance, between 11 and 25 per cent - low, between 26 and 50 per cent - medium, and above 50 per cent high significance. 
2. If ministerial attitudes towards the unions' underwent significant, swift, and enduring change then the unions' influence over policy may have changed.

The identification of significance shall depend on the nature of ministerial statements.

\section{Structures}

3. If union representation on government committees underwent significant, swift, and enduring change then the unions' influence over public policy may have changed.

Change below 10 per cent - no significance, between 11 and 25 per cent - low, between 26 and 50 per cent - medium, and above 50 per cent - high.

4. If the relationship between the unions, employers' peak organisation, and/or government, measured by economic partnership agreements, changed significantly, swiftly, and enduringly the trade unions' influence over public policy may have changed.

No change in relationship - no significance. Institution/dissolution of informal agreement between two parties - low, institution/dissolution of informal agreement between three parties - medium, and institution/dissolution of a formal agreement between two/three parties - high significance.

5. If union membership underwent significant, swift, and enduring change then the unions' influence over public policy may have changed.

Change below 1 per cent - no significance, between 1 and 2 per cent - low, between 2 to 3 per cent - medium, and above 3 per cent - high significance.

\section{Government Policies and Trade Union Policies}

6. If government policies towards labour, measured by statements, manifestos, coalition agreement, policy documents, and budgetary statements changed significantly, swiftly, and enduringly then the unions' influence on public policy may have changed.

Identification of significance shall be subjective, focusing on the qualitative aspect of government policies toward the unions.

7. If trade union policies incorporated into government's policies towards organised labour, measured by comparison of union policy documents with government policy documents, changed significantly, swiftly, and enduringly then the unions' influence over public policy may have changed.

Identification of significance will be subjective, depending upon the unions' judgement.

\section{Third Party Assessments of Government - Trade Union Relations}


8. If government's economic policies, as identified by organisations monitoring economic performance, underwent significant, swift, and enduring change then the unions' influence over public policy may have changed.

Identification of significance shall depend on the judgement of the organisations monitoring economic performance.

9. If union involvement in public policy, identified by national economic, political, and industrial relations commentators, changed significantly, swiftly, and enduringly then the unions' influence over public policy may have changed.

Identification of significance will depend upon the judgement of the commentators.

If drastic, swift, and enduring change in the unions' influence over public policy were recorded at the time of a macroeconomic crisis then a critical juncture has been uncovered. However, there will be variations in the level of empirical-theoretical fit for each of the hypotheses' observable implications. This raises the question of how many observables should point to an empirical-theoretical fit, and at what level they should point to this fit, to indicate a critical juncture. This is a subjective decision. Statisticians suggest that over 30 percent of observables at a high level of fit is a good result. However, we prefer to set a higher standard as many of our measures are subjective in nature. Here, a rule of 66 per cent is adopted. At least two thirds of all observable implications, for which there are findings, should point to high empiricaltheoretical fit for there to have been a critical juncture.

\section{Proposed Critical Juncture: Ireland 1959}

\section{H1. The State of the Economy}

$\underline{\text { Economic Indicators }}$

The 1950s were a depressed era for Ireland. The Economist points out that most indicators of economic performance were poor (EIU, 1992, p. 5). The benefits from protectionism had been reaped by the industrial expansion of the 1930s. By the 1950s Irish industry was supplying as much of the domestic market as it could. The economic indicators examined here are unemployment, inflation, debt/GNP, GDP growth, days lost to industrial disputes, and economic openness. As Appendix A shows, only two of these six indicators were at decade long lows in 1959, these were Debt/GNP, and economic openness. For the other 4 indicators their low points had passed during the 1950s. Nevertheless, none of these indicators could in anyway be called impressive, all pointing to the dire economic situation in the country.

As can be seen, all economic indicators improved consistently after 1959. Unemployment fell to roughly its natural level, inflation remained in single figures, debt stabilised to a large extent, and growth increase, while the number of days lost to industrial disputes fluctuated and economic openness increase.

Economic Opinions and Assessments 
The national and international media held negative views on the Irish economy. The Sunday Press argued that the second coalition government was defeated in 1957 by Fianna Fáil due to the general economic collapse, and a lack of will to tackle the problems at its heart. ${ }^{2}$ The Irish Times observed that employment was declining, unemployment increasing, hundreds of thousands emigrating, and the cost of living increasing. ${ }^{3}$ From abroad, The Economist pointed out that political matters, such as the voting system, were receiving Taoiseach de Valera's attention at the expense of the economy. The paper argued that 'righting the economy would be the paramount task facing the new Irish Taoiseach, Seán Lemass. ${ }^{4}$ The Irish Independent had little positive to say about the economy, alluding instead to the hope that with a new Taoiseach things might improve. ${ }^{5}$ Time International remarked that there had been few economic advances in Ireland during the 1950s, and that 40,000 of Ireland's most energetic young people were leaving annually. ${ }^{6}$

From the late 1940s onwards the Irish economy stagnated (Hillery, 1980, p. 46). 'By the middle of the 1950s a serious crisis of confidence had developed, caused by widespread anxiety that the performance of the economy was so poor the country was falling behind Western European standards, not only in productivity, but in the social benefits that productivity might be expected to confer (Lyons, 1973, p. 618). By the time De Valera returned to office in 1957 the economy had plumbed the depths of hopelessness (Whitaker, 1973, p. 415). 'In the 1950s, Ireland's relative [economic] performance was disastrous, poorer than that of the UK as well as the European average' (Gráda and O'Rourke, 1995, p. 214). Between 1951 and 1958 GDP rose by less than 1 per cent per year, employment declined by 12 per cent, unemployment rose, and half a million emigrated. The benefits from protectionism had been reaped by the industrial expansion of the 1930s (Haughton, 1995). Stop-go policies, in which an adverse balance of payments signalled that drastic fiscal actions were to follow, produced severe and largely unnecessary fiscal contractions in 1952 and 1957 (Kennedy and Dowling, 1975). In the late 1950s, the outlook for the economy was depressing, while the economies of Europe achieved strong and sustained growth (MacSharry and White, 2001, pp. 14-19). The delay in coming to terms with the failure of protectionism gave Ireland the status of a late starter (O'Malley, 1989). It was this mood of despair over the economy that permitted Lemass to subsequently slaughter a list of sacred political cows (Lee, 1989, p. 341).

By the late 1950s the Central Bank was expressing grave concerns about the economy. It agued that there was 'evidence of undue concentration, not only of financial resources, but of thought, energy, and administrative ability, on projects of questionable economic value. ${ }^{7}$ In a damning indictment of the economic situation, it stated that 'a study of events during the past ten years, of the courses that have been pursued, and of their consequences, is a necessary preliminary to the formulation of any sound proposals for the improvement of the national economy. ${ }^{8}$ The Central Bank also observed that 'the present economic and financial situation scarcely justifies the retention of confidence in large-scale expenditure on public works and social amenities as a means of stimulating useful economic activity and a progressive increase in real national income. ${ }^{9}$ It also pointed to the large external trade deficit. ${ }^{10}$ There had been an excess of imports over exports during the latter years of the decade. ${ }^{11}$ The Central Bank argued that a greater proportion of expenditure than could be afforded had been devoted to social purposes, while too little had been setaside for the future in the shape of protective investment. ${ }^{12}$ 'The total estimated numbers at work declined from 1956 through 1959. ${ }^{13}$ Despite the intensive development of sheltered industries catering for the home market, a high level of 
social investment, and large-scale external disinvestments and external borrowing, the problems of unemployment and emigration remained. ${ }^{14}$ In 1961 the Central Bank remarked that the 1950s had been a decade of economic stagnation. ${ }^{15}$

The OECD (1957, p. 11) observed that the condition of the Irish economy was not satisfactory. Between 1955 and 1958 the economy was affected by the restrictive measures adopted in 1955 to correct for a balance of payments deficit (OECD, 1964, p. 5). Consequently, gross national product declined. The numbers employed in manufacturing industry were no higher in 1958 than in 1951. The OECD $(1961$, p. 5) argued that the 1950s had been a time of terrible economic depression. Economic analysis of the country's performance showed agricultural production abnormally low, and industrial output faltering (OECD's, 1961, p. 8). The following year the OECD (1962, p. 5) commented that most of the post-war period was marked by slow and unbalanced growth in Ireland. The OECD $(1962$, p. 6) went on to state that per capita GNP grew at a rate of 2.4 per cent throughout the 1950s, but only because of 'the exceptional demographic experience during this period when net migration averaged forty-one thousand persons a year.' This per capita growth rate was among the lowest in the OECD (OECD, 1962, p. 6).

\section{Elected Representatives}

Government and opposition deputies recognized the economic crisis facing the country. 'They realised that the Irish economy could not survive in isolation' (Murphy, 1997, p. 57). Dr Donovan, in the Senate, warned of the trade deficit, national debt, stationary national income, and falling population. He stated that the fascination with equilibrium economics was insufficient for progress. ${ }^{16}$ Patrick Lindsey, in the Dail, stated it was a critical time for the economy. ${ }^{17}$ Tánaiste MacEntee argued that Ireland would have to face up to its economic difficulties if it was to maintain its status as a sovereign state. ${ }^{18}$ Opposition deputies accused the government of neglecting agriculture while sponsoring an ineffective industrial expansion. ${ }^{19}$ Daniel Desmond of Labour argued that it was time for the political establishment to realise that solving the problems with the economy superseded their power struggles. ${ }^{20}$ General Mulcahy, leader of Fine Gael, remarked that a tremendous effort would be required by all sections of the community to right the economy. ${ }^{21}$

Lemass remarked that the task for the generation of the 1950s was to consolidate the economic foundations of independence, and that 1959 was a crucial year for economic security. ${ }^{22}$ 'We have got to demonstrate beyond question the capacity to develop a viable economy.'23 The problem was that economic activity was not high enough to ensure good living standards for all. ${ }^{24}$ In late 1959 Lemass remarked that he, and the government, were ready to support any scheme of economic merit. $^{25}$ He said the government would not minimise the magnitude of the tasks facing the country, or the distance it was from realising it economic objectives. There was also the need to prepare the economy for the danger of balance of payments deficit, restrain consumer spending, ${ }^{26}$ and for measures to increase employment, and reduce emigration, both of which were very serious. Lemass commented that in the context of the economic problems the government was contending with the publication of the Programme for Economic Expansion indicated its conclusion that the measures previous undertaken were insufficient. ${ }^{27}$ 


\section{H2. Change in Union Influence over Public Policy}

\section{$\underline{\text { Access and Attitudes }}$}

When Lemass became Taoiseach he brought to government a vigorous entrepreneurial leadership (McCarthy, 1973, p. 22). A new approach was adopted towards both the economy and trade unions. Lemass "was prepared to offer the trade union movement an integral part in the development of much of the new thinking that lay behind the government's economic and social programme' (McCarthy, 1980, p. 32).

'In February 1959 the Irish Congress of Trade Unions (ICTU) was formally inaugurated' (Nevin, 1994, p. 96). Union unity gave the Taoiseach an opportunity to embark on national bargaining on wages policy, as there now existed a chance that the unions and employers could be brought together in a new framework that could achieve industrial progress without disputes (Horgan, 1997, p. 190).

'Shortly after Lemass became Taoiseach, he invited Congress to meet him to discuss the question of development' (Girvin, 1994, p. 125). Whereas the ICTU had only one meeting with Taoiseach de Valera in $1958,{ }^{28}$ it met with Lemass three times in 1959, and again in $1960 .^{29}$ The years thereafter saw more meetings, these focusing on a range of issues encompassing the economy and Ireland's policies towards the European Economic Community (EEC). This was in line with the call for more joint consultation between State, union, and employers in the First Programme for Economic Expansion. Lemass's speeches in 1959 often paralleled the positions adopted by Congress (Girvin, 1994, p. 125). These included the need for state involvement in development, and the expansion of the state sector. ${ }^{30}$

\section{$\underline{\text { Structures }}$}

There was change in the unions' representation on government committees. Appendix B shows that ICTU representation on industrial relations committees increased by 50 per cent, while representation on economic and social committees rose by 160 per cent. With the move towards the liberalisation of trade, and economic planning, Lemass was instrumental in the creation of consultative bodies involving the unions and employers (Lee, 1989, p. 401). This provided the ICTU with more avenues through which to influence public policy. Joint consultation was seen as extremely important for economic development (NIEC, 1966). Some of the new bodies the ICTU was represented upon included the Irish National Productivity Committee (INPC), a consultative body charged with improving industrial productivity. ${ }^{31}$ The Committee on Industrial Organisation (CIO), set up to examine the ability of Irish industry to compete within the EEC (Murphy, 1997, p. 62). The National Industrial and Economic Council (NIEC), established in 1963 as the main consultative body in economic planning. ${ }^{32}$ 'It was composed of members nominated by the Government, the ICTU and the FUE, state boards, and the FII' (Meenan, 1970, p. 157). These bodies, '[paralleling] the state's commitment to economic planning as contained in the first two programmes for economic expansion' (Girvin, 1994, p. 127) permitted the unions to co-operate with the state on a range of problems posed by economic expansion. 'A new pattern of participation by Congress in government institutions emerged between 1959 and 1965' (Girvin, 1994, p. 127). 
Consultative bodies, and joint consultation, gave the unions a new perception of their strength. 'The institutional setting soon became largely tripartite, with the representatives of business, of labour and of government discussing employment, output, prices and trade' (Pratschke, 1979, p. 43). 'From the countless tripartite meetings of these bodies, trade unionism was drawn inexorably into the framing of social and economic policies (Lynch, 1994, p. 169). Lynch argues that this later led to the National Pay Agreements, National Understandings, and the Programme for National Recovery. This shows that the government's policies towards organised labour underwent drastic change after 1959.

The declining union membership was arrested in 1959 (Appendix C). Between 1955 and 1958 trade union membership decreased by 9,600, falling to 306,800 in 1958. However, in 1959 membership increased by 6,900 , or 2.2 per cent, to 313,700 . In 1960 trade union membership increased again, by 3.8 per cent. Within five years of the proposed critical juncture there were upwards of 50,000 new members in Irish trade unions, an increase of 16 per cent. After 1959 trade union membership increased for the following 21 years.

\section{$\underline{\text { Government Policies and Trade Union Policies }}$}

The protectionist policies that had been continued after the war were reinforced during the 1950s (Girvin, 1994, p. 124). The late 1950s saw economic policy, as influenced by Secretary of the Department of Finance T K Whitaker's report Economic Development, shift from protectionism to export led industrialisation (Fitzpatrick and Kelly, 1985, p. xviii). 'Sooner or later, protectionism will have to go and the challenge of free trade accepted' (Department of Finance, 1958, p. 2). This constituted an admission of the failure of the economic philosophy underlying protectionism (O'Connell and Rottman, 1994, p. 234). Whitaker advanced a threepronged strategy for recovery: more planning, fewer tariff barriers, and greater emphasis on productive investment. 'Thus it was in the atmosphere of a new government and a more active and interventionist Department of Finance, that Economic Development was born' (Murphy, 2003, p. 61). 'In 1958 a symbolic, but nevertheless significant, act was the abolishing of the 1932 Control of Manufacturers Act which, was designed to keep industry in Irish hands' (Munck, 1993, p. 33).

Economic Development is regarded as 'a watershed in the modern economic history of the country' (Lyons, 1973, p. 628). It proposed opening the economy with the gradual transition to free trade, stimulation of private investment, the reorientation of government investment towards more productive uses, the introduction of grants and tax concessions to encourage export orientated manufacturing, and the inducement of direct investment by foreign export oriented manufacturers. ${ }^{33}$ The document advocated the abandonment of protectionism. ${ }^{34}$ These measures were incorporated into the First Programme for Economic Expansion in November 1958. The passing of the Industrial Development Act 1959 removed restrictions on foreign ownership of capital in Ireland. Speaking in the Dail in June 1959 Leamss remarked, on economic protectionism, that 'there is need now to raise our targets and, I believe, also change our methods. ${ }^{35} \mathrm{He}$ 'had been convinced since 1958 of the inevitability of free trade' (Whitaker, 1973, p. 418). The Central Bank observed that 'it is, of course, because of the continuing need for the promotion of increased productive activity at home that the redefinition of the objectives of economic policy represented by the government's statement was so necessary and is of so much importance. ${ }^{36}$ 
There was change in the government's policies toward trade unions. Lemass's perspective on economic development was close to the ICTU's. In June 1959 Lemass remarked on the need for change in industrial development policy. ${ }^{37} \mathrm{He}$ realised that government policy towards labour would have to change. 'The government began to look hopefully to the united Congress for support in its programme of national development' (McCarthy, 1980, p. 32). Adjusting industries to competition led public policy into the realms of labour practices, industrial relations, and pay bargaining. Lemass was prepared to offer the union movement an integral part in the development of the government's economic and social programme (McCarthy, 1980, p. 32). Moreover, government set out policy objectives in the area of employment similar to those of Congress (Girvin, 1994, p. 125). This gave to unions a new perception of their strength.

By 1960 budgets had expanded ${ }^{38}$ with increased investment in areas identified by Congress in policy documents and its private research. ${ }^{39}$ For the OECD (1961, p. 12) the Fianna Fail government's 1958 and 1959 budgets reflected a change in fiscal policy. In the subsequent capital budgets, investments that made no direct contribution to productive equipment were reduced. The OECD $(1961$, p. 10) found that encouragement to industry through grants and tax exemptions attracted foreign capital to Ireland. The government also pursued an increasingly liberal trade policy (OECD, 1962, p. 12).

\section{$\underline{\text { Third Party Assessments of Government - Trade Union Relations }}$}

Until the late 1950s the unions' influence in Ireland was mainly indirect (Allen, 1997, p. 181). However, at that time government's policies towards organised labour began to reflect the policies advocated by the unions. The ICTU Executive Council made representations to the Minister for Industry and Commerce in 1959 on legislation concerning annual leave with full pay, and minimum conditions of employment relating to holidays, overtime, and hours of work. ${ }^{40}$ The unions' views on company accounts influenced the Minister for Industry and Commerce in 1959. The recommendations of the Company Law Reform Committee, where the ICTU was represented, resulted in amendments to company law. ${ }^{41}$ In early 1960 the ICTU requesting an increase in pensions, and other social welfare benefit, to maintain their relationship with workers' wages. ${ }^{42}$ The subsequent budget increased social assistance benefits. ${ }^{43}$ In 1961 the ICTU and the Federated Union of Employers (FUE) reached agreement on the formation of the Employer-Labour Conference (ELC) that the government subsequently facilitated. ${ }^{44}$ This body, established in 1962, became central to corporate control (Lalor, 1982, p. 80). The budget of 1961 saw increases in social welfare payments ${ }^{45}$ in line with the recommendations of the ICTU's Social Welfare Committee. ${ }^{46}$ The union movement played a major part in the economic and social transformation that was coming (Nevin, 1994, p. 97). 'From the 1960s onwards, Congress pioneered the adoption of social policies now taken for granted' (Lynch, 1994, p. 169)

Lemass's realised that government policy towards organised labour would have to change. 'The government began to look hopefully to the united Congress for support in its programme of national development' (McCarthy, 1980, p. 32). The task of adjusting Irish industries to competition led public policy into the realms of labour practices, industrial relations, and pay bargaining. This gave to unions a new perception of the strength they possessed. Lemass realised that the success of 
government strategy assumed a new partnership with different interest groups, which would (in time) become players in the policy game (Murphy, 1997, p. 58).

Table 1 shows that 75 per cent of the observable implications for the first hypothesis indicated a high fit, pointing to a macroeconomic crisis. For the second hypothesis 70 percent of the observables pointed to high empirical-theoretical fit, indicating significant, swift, and enduring change in the unions' influence over public policy. This confirmed there was a critical juncture in the ICTU's influence over public policy in 1959.

Table 1: The Empirical-Theoretical Fit 1959

\begin{tabular}{|l|c|c|c|c|}
\hline The Observable Implications of Hypothesis 1 & High & Medium & Low & None \\
\hline $\begin{array}{l}\text { O1: Are the country's main economic } \\
\text { indicators at decade-long lows? }\end{array}$ & & & $\mathbf{X}$ & \\
\hline $\begin{array}{l}\text { O2: Do opinion polls find that the public } \\
\text { regards the economic state of the country as in } \\
\text { crisis? }\end{array}$ & & & $\mathbf{X}$ \\
\hline $\begin{array}{l}\text { O3: Do the national media regard the economic } \\
\text { state of the country as in crisis? }\end{array}$ & $\mathbf{X}$ & & & \\
\hline $\begin{array}{l}\text { O4: Do national economic and political } \\
\text { commentators regard the economic state of the } \\
\text { country as in crisis? }\end{array}$ & $\mathbf{X}$ & & & \\
\hline $\begin{array}{l}\text { O5: Does the central bank regards the } \\
\text { economic state of the country as in crisis? }\end{array}$ & $\mathbf{X}$ & & & \\
\hline $\begin{array}{l}\text { O6: Do domestic and international organisations } \\
\text { regard the economic state of the country as in crisis? }\end{array}$ & $\mathbf{X}$ & & & \\
\hline $\begin{array}{l}\text { O7: Do elected representatives regard the } \\
\text { economic state of the country as in crisis? }\end{array}$ & $\mathbf{X}$ & & & \\
\hline $\begin{array}{l}\text { O8: Are government pronouncements on the } \\
\text { state of the economy consistent with a crisis- } \\
\text { management approach? }\end{array}$ & $\mathbf{X}$ & & & \\
\hline & & & & \\
\hline The Observable Implications of Hypothesis 2 & High & Medium & Low & None \\
\hline $\begin{array}{l}\text { O1: Change in the trade unions' access to the } \\
\text { prime minister }\end{array}$ & $\mathbf{X}$ & & & \\
\hline $\begin{array}{l}\text { O2: Change in the trade union representation } \\
\text { on government committees }\end{array}$ & $\mathbf{X}$ & & & \\
\hline $\begin{array}{l}\text { O3: Change in the relationship in the economy } \\
\text { between the trade unions, the employers' peak } \\
\text { organisation, and/or the government }\end{array}$ & & $\mathbf{X}$ & & \\
\hline $\begin{array}{l}\text { O4: Change in the trade unions' relationship } \\
\text { with a political party }\end{array}$ & & & \\
\hline $\begin{array}{l}\text { O5: Change in the level of trade union } \\
\text { membership in the economy }\end{array}$ & & & \\
\hline $\begin{array}{l}\text { O6: Change in the government's policies } \\
\text { towards organised labour } \\
\text { policies towards organised labour }\end{array}$ & $\mathbf{X}$ & & \\
\hline $\begin{array}{l}\text { O7: Change in the level of trade union policies } \\
\text { that incorporated into the government's }\end{array}$ & $\mathbf{X}$ & & \\
\hline
\end{tabular}




\begin{tabular}{|l|l|l|l|l|}
\hline O8: Change in the government's economic & $\mathbf{X}$ & & & \\
policies & & & & \\
\hline $\begin{array}{l}\text { O9: Change in the trade unions' influence over } \\
\text { public policy as identified by national } \\
\text { economic, political, and industrial relations } \\
\text { commentators alike }\end{array}$ & $\mathbf{X}$ & & & \\
\hline $\begin{array}{l}\text { O10: Change in ministerial attitudes towards } \\
\text { the role of trade unions in the polity }\end{array}$ & $\mathbf{X}$ & & & \\
\hline
\end{tabular}

\section{Conclusion}

Historical institutionalism explores the conditions under which institutions have consequences. The most successful aspect of this literature is the understanding it has provided of policy continuities within countries, and variations across countries. However, this approach treats institutions as static variables. Consequently, it provides accounts that fail to capture the essence of change.

In political science there are few tools with which to make sense of institutional change (Thelen, 2003, p. 234). Katznelson (2003, p. 283) points to this deficiency, arguing that scholarship has yet to move purposefully in this direction. Consequently, any new, or revised, instruments should be welcomed. This paper elaborated a theoretical framework to evaluate critical junctures. This will help in assessing claims about the significance of change.

Employing the criteria set out above for specifying a critical juncture will help researchers make more plausible claims that certain outcomes were critical junctures, or watershed, and other were not. Along with elaborating the theoretical framework with which one evaluates critical junctures, this could represent a big advance for historical institutionalism and path-dependent research. An understanding of critical junctures would provide us with a means of defining the starting point for any path dependent analysis, solving the infinite regress problem.

The paper sought to set within its theoretical context, and test, the revised critical junctures approach. The remoulded approach, possessing clarity, rigour, and a focus on context previously lacking in the literature, was employed in examining change in the ICTU's influence over public policy in 1959 (See Figure 3). At that time the economy was in crisis, and the unions' influence over public policy underwent change of a significant, swift, and enduring nature. The empiricaltheoretical fit, as set out in Table 1, was very high for both hypotheses, confirming there had been a critical juncture in the ICTU's influence over public policy in 1959.

With the systemisation of standards it was easier identify a critical juncture. The remoulded approach reduces uncertainty surrounding the concept. Most importantly, the remoulded critical junctures approach is applicable to any research concerned with the identification of change. This raises the prospect of wide ranging research employing the remoulded critical junctures approach in future.

FIGURE 3: THE CRITICAL JUNCTURE GRID FOR ALL FOUR COUNTRIES

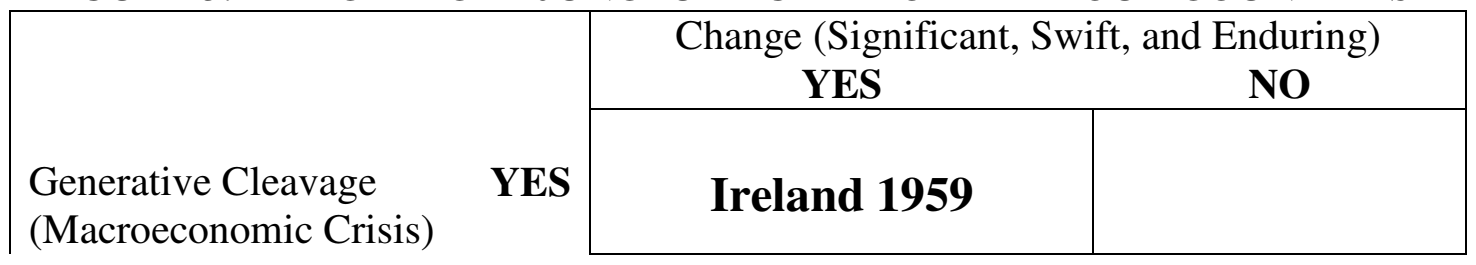




\begin{tabular}{|l|l|l|}
\cline { 2 - 3 } & & \\
\cline { 3 - 4 } No & & \\
\end{tabular}

\section{APPENDIX A}

Ireland's Main Economic Indicators, 1949 - 1969

\begin{tabular}{|l|l|l|l|l|l|r|}
\hline Year & Unemployment & Inflation & $\begin{array}{c}\text { Government } \\
\text { Debt to GNP } \\
\text { ratio }\end{array}$ & $\begin{array}{l}\text { Growth Rates } \\
\text { in Real Gross } \\
\text { Domestic } \\
\text { Product }\end{array}$ & $\begin{array}{c}\text { Industrial } \\
\text { Disputes days } \\
\text { lost (thou) }\end{array}$ & $\begin{array}{c}\text { Economic } \\
\text { Openness }\end{array}$ \\
\hline 1950 & 7.5 & 0.0 & & 1.9 & 217 & 70.93345 \\
\hline 1951 & 7.3 & 11.25 & 49.9 & 1.9 & 545 & 82.55222 \\
\hline 1952 & 9.1 & 10.1 & & 2.26 & 529 & 69.63176 \\
\hline 1953 & 9.6 & 2.04 & & 2.5 & 82 & 66.85665 \\
\hline 1954 & 8.1 & 2.0 & & 0.9 & 67 & 65.45109 \\
\hline 1955 & 6.8 & 1.9 & & 1.9 & 236 & 67.17816 \\
\hline 1956 & 7.7 & 4.4 & 52.9 & -1.45 & 48 & 60.98576 \\
\hline 1957 & 9.2 & 2.57 & 53.7 & 0.98 & 92 & 62.7357 \\
\hline 1958 & 8.6 & 2.6 & 54.2 & -2.2 & 126 & 62.86433 \\
\hline $\mathbf{1 9 5 9}$ & $\mathbf{8 . 0}$ & $\mathbf{- 0 . 8 5}$ & $\mathbf{5 5 . 5}$ & $\mathbf{4 . 1}$ & $\mathbf{1 2 4}$ & $\mathbf{6 2 . 7 3 2 0 7}$ \\
\hline 1960 & 6.7 & 0.86 & 57.5 & 5.0 & 80 & 64.68637 \\
\hline 1961 & 5.0 & 2.8 & 57.8 & 3.2 & 377 & 69.80739 \\
\hline 1962 & 4.8 & 4.3 & 58.3 & 3.1 & 104 & 66.89395 \\
\hline 1963 & 5.0 & 2.5 & 58.93 & 4.7 & 234 & 70.08703 \\
\hline 1964 & 4.7 & 6.7 & 55.2 & 3.8 & 545 & 74.32474 \\
\hline 1965 & 4.6 & 5.0 & 58.7 & 1.9 & 556 & 75.72556 \\
\hline 1966 & 4.7 & 3.0 & 59.7 & 0.7 & 784 & 74.11819 \\
\hline 1967 & 5.0 & 4.8 & 58.3 & 4.8 & 183 & 79.36693 \\
\hline 1968 & 5.0 & 5.0 & 59.2 & 8.1 & 406 & 79.29319 \\
\hline 1969 & 5.0 & 7.4 & 55.9 & 4.7 & 936 &
\end{tabular}

\section{Appendix B}

ICTU Representation on Committees pre and post 1959

\begin{tabular}{|c|c|c|}
\hline & $1957 / 1958$ & 1960/1961 \\
\hline $\begin{array}{l}\text { Industrial } \\
\text { Relations }\end{array}$ & $\begin{array}{l}\text { Factories Advisory Council } \\
\text { Safety Committees } \\
\text { National Joint Committee on the } \\
\text { Human Sciences } \\
\text { Human Problems in Industry } \\
\text { Transport Committee }\end{array}$ & $\begin{array}{l}\text { Employer Labour Confernece } \\
\text { Factories Advisory Council } \\
\text { Safety Committees } \\
\text { National Joint Committee on the } \\
\text { Human Sciences } \\
\text { Human Problems in Industry } \\
\text { Hours of Work } \\
\text { Transport Committee } \\
\text { Apprenticeships Committee } \\
\text { Harbour Boards }\end{array}$ \\
\hline
\end{tabular}




\begin{tabular}{|l|l|l|}
\hline $\begin{array}{l}\text { Economic } \\
\text { and Social }\end{array}$ & $\begin{array}{l}\text { Price Advisory Committee } \\
\text { Commission on Income Tax }\end{array}$ & NIEC \\
& & Price Advisory Committee \\
Commission on Income Tax \\
& & Company Law Reform Committee \\
& & Price Advisory Committee \\
& & Irish National Prodictivity Committee \\
& Economic Committee \\
& Committee on Industrial Organisation \\
\hline
\end{tabular}

\section{Appendix C}

Membership Changes in ITCU and CIU (pre 1959); and ICTU (post 1959)

\begin{tabular}{|l|c|c|c|c|}
\hline & Membership & $\begin{array}{l}\text { Annual Rate of } \\
\text { Change \% }\end{array}$ & $\begin{array}{l}\text { Employment } \\
\text { Density \% }\end{array}$ & $\begin{array}{l}\text { Workforce } \\
\text { Density \% }\end{array}$ \\
\hline 1955 & 316,400 & +1.7 & 45.6 & 42.7 \\
\hline 1956 & 316,500 & 0.0 & 46.2 & 43.1 \\
\hline 1957 & 308,200 & -2.5 & 46.5 & 42.3 \\
\hline 1958 & 306,800 & -0.4 & 46.9 & 42.4 \\
\hline $\mathbf{1 9 5 9}$ & $\mathbf{3 1 3 , 7 0 0}$ & $+\mathbf{2 . 2}$ & $\mathbf{4 7 . 9}$ & $\mathbf{4 3 . 7}$ \\
\hline 1960 & 325,500 & 3.8 & 50.2 & 45.8 \\
\hline 1961 & 335,600 & +3.1 & 52.4 & 48.2 \\
\hline 1962 & 348,500 & +3.8 & 53.5 & 49.4 \\
\hline 1963 & 351,000 & +0.7 & 53.0 & 48.9 \\
\hline 1964 & 362,300 & +3.2 & 53.8 & 49.9 \\
\hline 1965 & 371,900 & +2.6 & 54.4 & 50.7 \\
\hline 1966 & 372,500 & +0.2 & 53.7 & 49.9 \\
\hline 1967 & 377,700 & +1.4 & 54.2 & 50.2 \\
\hline 1968 & 389,800 & +3.2 & 55.1 & 50.8 \\
\hline 1969 & 409,200 & +5.0 & 57.0 & 52.9 \\
\hline
\end{tabular}

\section{References}

Abbott, Andrew, 1997. 'On the Concept of Turning Point,' Comparative Social Research. Vol. 16, pp. 85-105.

Allen, Kieran, 1997. Fianna Fáil and Irish Labour: 1926 to the Present. London: Pluto Press.

Aminzade, Roy, 1992. 'Historical Sociology and Time,' Sociological Methods and Research. Vol. 10, pp. 456-80.

Berman, Sheri, 1998. 'Path Dependency and Political Action: Reexamining Responses to the Depression,' Comparative Politics, Vol. 30, No. 4, pp. 379-400.

Brady, David, 1988. Critical Elections and Congressional Policy-Making. Stanford: Stanford University Press. 
Braudel, F., 1973. The Mediterranean and the Mediterranean World in the Age of Philip II. London: Collins.

Casper, Gretchen, and Michelle M. Taylor. 1996. Negotiating Democracy: Transitions from Authoritarian Rule. Pittsburgh: University of Pittsburgh Press.

Collier, R. B., and Collier, D. (1991) Shaping the Political Arena: Critical Junctures, the Labour Movement, and Regime Dynamics in Latin America. Princeton, NJ: Princeton University Press.

Cortell, A. P., and Peterson, S. (1999) 'Altered States: Explaining Domestic Institutional Change,' British Journal of Political Science, 29, 177-203.

David, Paul A., 1985. 'Clio and the Economics of QWERTY,'American Economic Review, Vol. 75, No. 2, pp. 332-337.

Department of Finance, 1958. Economic Development. Dublin: Stationary Office.

Eisenhardt, M., 1989. 'Building theories from case study research', Academy of Management Review, Vol. 14, pp. 532-50.

Fitzpatrick, Jim and John Kelly, 1985. Perspectives on Irish Industry. Dublin: Irish Management Institute

Gal, John, and David Bargal, 2002. 'Critical Junctures, Labour Movements and the Development of Occupational Welfare in Israel,' Social Problems, Vol. 49, No. 3, pp. 432-454.

Garrett, G. (1993) The Politics of Structural Change: Swedish Social Democracy and Thatcherism in Comparative Perspective,' Comparative Political Studies, 25 (4), 521547.

Garrett, Geoffrey, and Peter Lange, 1995. 'Internationalization, Institutions, and Political Change,' International Organization, Vol. 49, No. 4, pp. 627-655.

Girvin, Brian, 1994. 'Trade Unions and Economic Development,' in Donal Nevin (ed.), Trade Union Century. Cork: Mercier Press.

Haggard, Stephan, 1988. 'The Institutional Foundations of Hegemony: Explaining the Reciprocal Trade Agreements Act of 1934,' International Organization, Vol. 42, No. 1 pp. 91-119.

Haughton, Jonathan, 1995. 'The Historical Background,' in John W. O'Hagan (ed.), The Economy of Ireland: Policy and Performance of a Small European Country. Dublin: Gill and Macmillan.

Hillery, Brian, 1980. 'Industrial Relations: Compromise and Conflict,' in Donal Nevin (ed.), Trade Unions and Change in Irish Society. Dublin: Mercier Press.

Horgan, J. (1997) Seán Lemass: The Enigmatic Patriot. Dublin: Gill \& Macmillan. 
Karl, Terry Lynn, 1997. The Politics of Plenty: Oil Booms and Petro-States. Berkeley: University of California Press.

Katznelson, Ira, 1997. 'Structure and Configuration in Comparative Politics,' in M. Lichbach and A. Zuckerman (eds.), Comparative Politics: Rationality, Culture and Structure. New York: Cambridge University Press.

Katznelson, Ira, 2003. 'Periodization and Preferences,' in James Mahoney and Dietrich Rueschemeyer (eds.) Comparative Historical Analysis in the Social Sciences. Cambridge: Cambridge University Press.

Kennedy, K. A., and B. R. Dowling, 1975. Economic Growth in Ireland: The Experience Since 1947. Dublin: Gill and Macmillian.

Kerr, C. (1960) Industrialism and Industrial Man. Cambridge: Harvard University Press.

King, Gary, Robert O. Keohane, and Sidney Verba, 1994. Designing Social Inquiry: Scientific Inference in Qualitative Research. Princeton, NJ: Princeton University Press.

Krasner, Stephen D., 1984. 'Approaches to the State: Alternative Conceptions and Historical Dynamics,' Comparative Politics, Vol. 16, No. 2, pp. 223-246.

Lalor, Stephen, 1982. 'Corporatism in Ireland,' Administration, Vol. 30, No. 4, pp. 74-97.

Lee, J. J., 1989. Ireland, 1912-1985: Politics and Society. Cambridge: Cambridge University Press.

Levi, Margaret, 1997. 'A Model, a Method, and a Map: Rational Choice in Comparative and Historical Analysis,' in Mark Irving Lichbach and Alan S. Zuckerman (eds.), Comparative Politics: Rationality, Culture, and Structure. Cambridge: Cambridge University Press.

Lipset, Seymour Martin, (1983) 'Radicalism or Reformism: The Source of WorkingClass Politics,' American Political Science Review, 77 (1), 1-18.

Lipset, Seymour Martin, and Stein Rokkan, 1967. 'Cleavage Structures, Party Systems, and Voter Alignments: An Introduction,' in Seymour Martin Lipset and Stein Rokkan (eds.), Party Systems and Voter Alignments: Cross-National Perspectives. New York: Free Press.

Lynch, Patrick, 1994. '1894-1994: An Overview' in Donal Nevin (ed.), Trade Union Century. Cork: Mercier Press.

Lyons, F. S. L., 1973. Ireland Since the Famine. London: Fontana. 
MacSharry, Raymond, and Padraic White, 2001. The Making of the Celtic Tiger: The Inside Story of Ireland's Boom Economy. Cork: Mercier

Mahoney, James, 2000. 'Path Dependence in Historical Sociology,' Theory and Society. Vol. 29, No. 4, pp. 507-548.

Mahoney, James, 2001. 'Path Dependent Explanations of Regime Change: Central America in Comparative Perspective,' Studies in Comparative International Development. Vol. 36, No. 1, pp. 111-141.

Mahoney, James, 2003. 'Long-Run Development and the Legacy of Colonialism in Spanish America. American Journal of Sociology. Vol. 109, No. 1, pp. 50-106.

McCarthy, C. (1973) The Decade of Upheaval: Irish Trade Unions in the 1960s. Dublin: Institute of Public Administration.

McCarthy, C. (1980) 'The Development of Irish Trade Unions,' in Donal Nevin (ed.), Trade Unions and Change in Irish Society. Dublin: Mercier Press.

Meenan, James, 1970. The Irish Economy Since 1922. Liverpool: Liverpool University Press

Munck, Ronnie, 1993. The Irish Economy: Results and Prospects. Pluto Press: London.

Murphy, Gary, 1997. 'Government, Interest Groups and the Irish Move to Europe,' Irish Studies in International Affairs, Vol. 8, pp. 57-68.

Murphy, Gary, 2003. Economic Realignment and the Politics of EEC Entry: Ireland 1948-1972. Bethesda, MD: Academica Press.

National, Industrial and Economic Council (NIEC), 1966. Arrangement for Planning at Industry Level. Dublin: NIEC

Nevin, D., 1994. 'Decades of Dissension and Division 1923-1959,' in Donal Nevin (ed.), Trade Union Century. Cork: Mercier Press.

O'Connell, P. J., and Rottman, D. B. (1994) 'The Welfare State,' in J. H. Goldthorpe and C. T. Whelan (eds.), The Development of Industrial Society in Ireland. Oxford: Oxford University Press.

Ó'Gráda, C., and O’Rourke, K. (1993) Irish Economic Growth, 1945-1988. Dublin: University College Dublin.

Ó'Gráda, Cormac, and Kevin O' Rourke, 1995. 'Economic Growth: Performance and Explanations,' in John W. O'Hagan (ed.), The Economy of Ireland: Policy and Performance of a Small European Country. Dublin: Gill and Macmillan.

O’Malley, Eoin, 1989. Industry and Economic Development: The Challenge for the Latecomer. Dublin: Gill and Macmillan. 
Organisation for European Economic Cooperation, 1957. Ireland and Portugal 1957. Paris: OEEC.

Organisation for European Economic Cooperation, 1961. Ireland 1961. Paris: OEEC.

Organisation for Economic Cooperation and Development, 1962. Ireland 1962. Paris: OECD.

Organisation for Economic Cooperation and Development, 1964. Ireland 1964. Paris: OECD.

Peters, B. Guy, 1999. Institutional Theory in Political Science: The New Institutionalism. London: Pinter.

Pierson, Paul, 1993. 'When Effects become Cause: Policy Feedback and Political Change,' World Politics. Vol. No. pp. 595-628

Pierson, Paul, 2000. 'Increasing Returns, Path Dependency, and the Study of Politics,' American Political Science Review. Vol. 94, No. 2, pp. 251-267.

Pierson, Paul, 2004. Politics in Time: History, Institutions, and Social Analysis. Princeton University Press: Princeton, NJ.

Pratschke, John L., 1970. 'Business and Labour in Irish Society, 1945-70,' in J. J Lee (ed.), Ireland 1945-70. Dublin: Gill and Macmillan.

Rothstein, Bo, 1996. 'Political Institutions: An Overview,' in Robert E. Goodin and Hans-Dieter Klingmann (eds.), A New Handbook of Political Science. Oxford: Oxford University Press.

Schickler, Eric, 2001. Disjointed Pluralism: Institutional Innovation and the Development of the U.S. Congress. Princeton, NJ: Princeton University Press.

Stark, David, and Laszlo Bruszt, 1998. 'Enabling Constraints. Institutional Sources of Policy Coherence and Extended Accountability' in David Stark and Laszlo Bruszt (eds.), Postsocialist Pathways: Transforming Politics and Property in Eastern Europe. Cambridge: Cambridge University Press

Steinmo, Sven, 1989. 'Political Institutions and Tax Policy in the United States, Sweden, and Britain.' World Politics, Vol. 41, No. 4, pp. 500-535.

Stinchcombe, A. L. (1968) Constructing Social Theories. New York: Harcourt, Brace and World.

The Economist Intelligence Unit, 1992. 'Ireland: Country Profile 1991-92.'

Thelen, Kathleen, 2003. 'How Institutions Evolve: Insights from Comparative Historical Analysis,' in James Mahoney and Dietrich Rueschemeyer (eds.) 
Comparative Historical Analysis in the Social Sciences. Cambridge: Cambridge University Press.

Thelen, Kathleen, and Sven Steinmo, 1992. 'Historical Institutionalism in Comparative Politics,' in Sven Steinmo, Kathleen Thelen, and Frank Longstreth (eds.), Structuring Politics: Historical Institutionalism in Comparative Analysis. Cambridge: Cambridge University Press.

Tilly, C. (1975) The Formation of Nation States in Western Europe. Princeton, NJ: Princeton University Press.

Valenzuela, J. Samuel, 1979. Labour Movement Formation and Politics: The Chilean and French Cases in Comparative Perspective, 1850-1950. Doctoral Dissertation, Department of Sociology, Colombia University.

Valenzuela, J. Samuel, and Arturo Valenzuela, 1981. 'Modernization and Dependency: Alternative Perspectives in the Study of Latin American Underdevelopment,' in Heraldo Munoz (ed.), From Dependency to Development. Boulder, CO: Westview Press.

Vargas, Vicente, 2004. The Political Dynamic of the Conflict in Chiapas: A History of its Critical Junctures. Paper Presented as Centre of Latin American Studies Research Day, University of Cambridge.

Verba, S. (1971) 'Sequences and Development,' in Leonard Binder (ed.), Crises and Sequences in Political Development. Princeton: Princeton University Press.

Whitaker, T. K., 1973. 'From Protection to Free Trade - the Irish Case,' Administration, Vol 21 No. 4, pp 405 - 423.

Yin, R., 1994. Case Study Research: Design and Methods. London: Sage.

\footnotetext{
${ }^{1}$ Armingeon, Klaus and Michelle Beyeler, Critical Junctures, An International Comparison.

http://www.ipw.unibe.ch/mitarbeiter/armingeon/Armingeon Klaus/Forschungsprojekte/Critical junctures.pdf.

${ }^{2}$ The Sunday Press, 25 January, 1987, p. 12.

${ }^{3}$ The Irish Times, 24 June, 1959, p. 6.

${ }^{4}$ The Economist, 4 July, 1959, p. 15.

${ }_{6}^{5}$ Irish Independent, June 27, 1959, p. 7.

${ }^{6}$ Time International, 29 June, 1959, Vol. 73, No. 26, p. 24.

${ }^{7}$ The Central Bank of Ireland, Annual Report, 1957, p. 35.

${ }^{8}$ The Central Bank of Ireland, Annual Report, 1959, p. 32.

${ }^{9}$ The Central Bank of Ireland, Annual Report, 1957, p. 34.

${ }^{10}$ ibid., 1957, p. 27.

${ }^{11}$ The Central Bank of Ireland Quarterly Statistical Bulletin, January, 1960, p. 4.

${ }^{12}$ ibid., 1958, p. 30.

${ }^{13}$ Central Bank of Ireland, Annual Report, 1961, p. 28.

${ }^{14}$ Central Bank of Ireland, Annual Report, 1959, p. 24.

${ }^{15}$ Central Bank of Ireland, Annual Report, 1961, p. 5.
} 
${ }^{16}$ Dáil Eireann, Vol. 51, 15 July, 1959.

${ }^{17}$ Dáil Eireann, Vol. 117, 11 December, 1959.

${ }^{18}$ Dáil Eireann, Vol. 51, 29 June, 1959.

${ }^{19}$ The Times, 24, June, 1959, p. 7.

${ }^{20}$ The Irish Independent, 24 June, 1959.

${ }^{21}$ Dáil Eireann, Vol. 171, 2 December, 1958.

${ }^{22}$ The Irish Times, 25 June, 1959.

${ }^{23}$ Dáil Eireann, Vol. 174, 28 April, 1959.

${ }^{24}$ ibid., 24 April, 1959.

${ }^{25}$ Dáil Eireann, Vol. 51, 11 December, 1959.

${ }^{26}$ ibid.

${ }^{27}$ Dáil Eireann, Vol. 174, 28 April, 1959.

${ }^{28}$ A[nnual] R[eport], I[rish] C[ongress] of T[rade] U[nions], 1959.

${ }^{29}$ AR, ICTU, 1960.

${ }^{30}$ Dáil Eireann, Vol. 176, 21 July, 1959.

${ }^{31}$ AR, ICTU, 1963.

${ }^{32}$ AR, ICTU, 1964.

${ }^{33}$ Economic Development, 1958.

${ }^{34}$ ibid.

${ }^{35}$ Dáil Eireann, Vol. 175, 5 June, 1959.

${ }^{36}$ Central Bank of Ireland, Annual Report, 1959, p. 28.

${ }^{37}$ Dáil Eireann, Vol. 175, 3 June, 1959.

${ }^{38}$ Budget, 1960, 1961, 1962.

${ }^{39}$ N[ational] A[rchives] D[epartment] of the T[aoiseach]: ICTU Archive, Box 42 Economic Policy, 4002, 'Meeting with the Taoiseach 1959.'

${ }^{40}$ AR, ICTU, 1960.

41 ibid.

42 ibid.

${ }^{43}$ ibid.

${ }^{44}$ AR, ICTU, 1961.

${ }^{45}$ Budget, 1961.

${ }^{46}$ AR, ICTU, 1961. 